\title{
命題を集合と同一視すること 包括原理からカリー＝ハワード対応へ
}

岡本賢吾

\begin{abstract}
Mathematical structures are identified with classes (in naive set theories, which were based on Comprehension Principle), or with sets (in axiomatic set theories, which adopted the principle in its restricted form). By analyzing abstraction operators and the set-theoretical diagonal arguments, the author indicates both classes and sets could be best regarded as certain self-applicable functions, treated as objects on their own. On the other hand, contemporary higher-order type theories, guided by the Curry-Howard Isomorphism, identify mathematical structures with propositions. According to this conception, formal derivation of a judgment counts both as the proof of a proposition and as the construction of a structure. The author examines its significance to the study of how language contributes to the construction of mathematical structures.
\end{abstract}

標準的な古典一階述語論理の言語 Lを考え，そこにクラス演算子とメン バー関係記号，それから後掲の［述定原理］を付け加えたとする．これはつ まり，Lに包括原理（comprehension principle）を組み込むということであ る. (詳しくは次節で述べる). 本稿では，とりあえずこの言語を「素朴クラ ス理論 NC」と呼んでおこう。すると言うまでもなく,ラッセルのパラドクス により，NCは矛盾を含む。しかし同時に，ともかくこうした単純な言語で 
あっても，NCは, 包括原理のおかげで, きわめて多様な構造（集合，あるい はクラス）を表示するためのターム，つまり，それらの構造に対するクラス 抽象（class abstraction）を形成することができる：その際もちろん，(ここ でもパラドクスの問題が絡むとはいえ）各々のクラス抽象が, 意図された構 造を表示しているということも，基本的には［述定原理］に基づいて確認可 能である。一例として, よく知られたものではあるが，NCを用いて構成可能 な自然数領域 $\mathrm{N}$ の定義を示しておこう.

[NCによる自然数領域の構成]

$$
\begin{aligned}
& 0=\text { def. }\{\mathrm{x} \mid \neg \mathrm{x}=\mathrm{x}\} \\
& \operatorname{Succ}(\mathrm{x})=\text { def. }\{\mathrm{y} \mid \mathrm{y}=\mathrm{x} \vee \mathrm{y} \in \mathrm{x}\} \\
& \text { Ind =def. }\{\mathrm{z} \mid 0 \in \mathrm{z} \wedge \forall \mathrm{y}(\mathrm{y} \in \mathrm{z} \rightarrow \operatorname{Succ}(\mathrm{y}) \in \mathrm{z})\} \\
& \mathrm{N}=\text { def. } \cap \text { Ind }=\{\mathrm{x} \mid \forall \mathrm{z}(\mathrm{z} \in \operatorname{Ind} \rightarrow \mathrm{x} \in \mathrm{z})\}
\end{aligned}
$$

さて, 以上のような言語構築のやり方, つまり, L (あるいは更に, 二階以 上の述語論理）の言語に包括原理を組み込むというやり方は，確かにそのま までは挫折に終わるとはいえ，次のような問いに対して，一つの代表的な回 答例を与えていると言ってよいだろう。その問いとは, 論理的・数学的な諸 構造に対する原始的な定項も存在公理も一切含まないような言語，つまり， 構造の名前を元々まったく持たず, また存在公理によってそれらの存在を要 請することもないいわば“純粋な言語”一 $\mathrm{NC}$ は確かにその一例である一 を用いて, 様々の構造の定義や構成を行うことは, 一体どうすれば（言語内 にどのような原理を組み込めば）可能となるのか，ということである．この 問いにどのようなポイントがあるかを論じようとするとそれ自体複雑になる が，おそらくその趣旨はおおよそ理解されるであろう.実際，ごく簡単に言っ ても，この問いを検討することからは，一般に言語は，様々な構造（とりわ け，数学に登場する諸構造）に対してどのような関わりを持つのか，言語か ら出発して構造に至るためにはどのような道筋があるのか, といった問題に ついての洞察を期待することができるはずだと思われる.

併せて言えば，よく知られている通り，歴史上の事実として見ても，例え ばフレーゲは, まさに以上のような問題を考察したと考えられるし，その結 果として, 概念記法の体系を通じて彼がこの問題に対して与えた答えは，そ の単純な骨格だけ取り出せば, (パラドクスに襲われたことまで含めて) 基本 的には以上の NCと同じであった（ただし厳密には, 彼の体系では二階量化 が可能なため, メンバー関係記号に当たるものが定義可能となるという違い があるが, この点はここでは措いてもよいであろう)。この意味で, 実際に包 括原理は，彼により，上で述べた問いに答えるための鍵として採用されたわ 
けである。

というわけで, 当然, 次に問題となってくるのは, 包括原理の利点や力能 をできるだけ保存しながら，しかもパラドクスを回避しようとすると一体ど うなるのか，ということであろう。そして実際に，現在ではこの問題につい ていくつも注目すべき成果が得られている.(例えば, NCに極めて近い体系 一包括原理は全面的に保存しつつ, むしろ論理の面に一定の制限を課すこ とで, パラドクスを克服したもの一一で, 十分強力な範囲の自然数論を展開 しうるような大変興味深い集合論が開発されている1. しかしながら, 本稿で は，そうした問題ではなく，敢えて次のような問題を検討してみたい。すす わちそれは，そもそも，上で述べた問い一構造のための定項も存在公理も 含まない純粋な言語によって, 構造の構成を行うためには, 言語内にどのよ うな原理を組み込む必要があるか一に答えうるようなものとして, 包括原 理以外の考え方は存在しないのか, 存在するとすればそれはどのようなもの であり，単純な技術的優劣といったことは別として，包括原理との最も重要 な違いはどこにあるのか, という問題である。この問題もまた, 先に触れた, 言語から出発して構造に至るためにはどのような道筋があるのかという関心 に繋がることは言うまでもない，それだけでなく，逆に，包括原理を採用し ようとすることは何をすることなのか, この原理のうちには, 言語と構造の 間の連関についてのどのような特徵的な見方が前提されているのか, という 点をも，外側から照射することが可能ではないかと期待される. 本稿の基本 にあるのはこのような関心である.

それでは，果たして実際に，包括原理以外に，そのような考え，原理とい うのは存在するだろうか.

一例として言うと, 筆者の理解するところでは, 現代の高階タイプ理論 (型 付ラムダ計算）の或る種の体系（いわゆる体系F）は，確かにそうした考え 方の一つを提示していると言ってよいと思われる ${ }^{2}$. 興味深いことに, そこで 得られる回答は, NCのように包括原理に依拠する場合と比べて, 或る意味で 遥かに単純なものである，すなわち，Fが教えているのは，第一に，ごく当

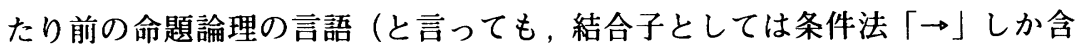
まず, 他方で, 全称命題量化子「П」が導入されている, という独特さがあ るが——なお, 命題定項は一切不要である) に登場する命題変項は, 実は, そ の命題変項としての論理的振る舞いを保ったままで, 同時に, 構造（Fの用 語ではタイプ）一般に対する変項，つまりタイプ変項犬゙と考えてよい（同一 視してよい）ということ，第二に，同様にして，命題変項に様々に条件法結

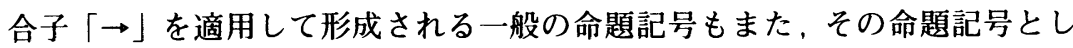


ての振る舞いを保ったまま，構造（タイプ）に対するタームだと考えてよい ということ（この場合，条件法結合子は，構造，タイプに対する操作という 観点から言えば，関数空間を採る演算子に当たっている），そして第三に，全 称量化を受けた閉じた諸命題，とりわけ，通常の命題論理の諸定理の全称化 (つまり, 高階命題論理の定理)は,それぞれ何らかの確定的な構造，しかも， 重要で基礎的な数学的諸構造 (データ・タイプ)を表示すると考えてよい, と いうことである。

もちろんこの場合, 問題は単に, 高階命題論理について変わった解釈を行 うといったことなのではない.そうではなく,ここでは同時に, 命題論理の 言語にラムダ計算の言語が重ね合わせられており(ラムダ演算子については, 次節でもっと詳しく取り上げる)，命題論理の中で行われる証明の各ステップ に対して，ラムダ項を用いて，いわゆる証明タームが組み合わせられる形に なっている。その推論規則（型付け規則）については，後にその初等的な部 分を紹介するが，ここで結果だけを簡単に見てみると，例えばまず，

$$
\Phi \rightarrow((\Phi \rightarrow \Phi) \rightarrow \Phi)
$$

という（量化を含まない）定理の一例については，次のような様々な（無限

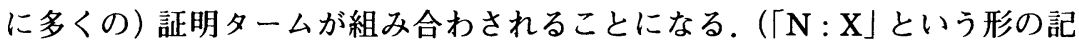
号結合は「判断」と呼ばれ，簡単には「 $\mathrm{N}$ は X証明である」と読んでよい).

$$
\begin{aligned}
& \lambda \mathrm{x}: \Phi \lambda \mathrm{y}: \Phi \rightarrow \Phi . \mathrm{x}: \Phi \rightarrow((\Phi \rightarrow \Phi) \rightarrow \Phi) \\
& \lambda \mathrm{x}: \Phi \lambda \mathrm{y}: \Phi \rightarrow \Phi . \mathrm{y}(\mathrm{x}):: \quad \Phi \rightarrow((\Phi \rightarrow \Phi) \rightarrow \Phi)
\end{aligned}
$$

$\lambda \mathrm{x}: \Phi \lambda \mathrm{y}: \Phi \rightarrow \Phi \cdot \mathrm{y}(\mathrm{y}(\mathrm{x})): \Phi \rightarrow((\Phi \rightarrow \Phi) \rightarrow \Phi)$

$\lambda \mathrm{x}: \Phi \lambda \mathrm{y}: \Phi \rightarrow \Phi \cdot \mathrm{y}(\ldots(\mathrm{y}(\mathrm{y}(\mathrm{x}))) \ldots): \Phi \rightarrow((\Phi \rightarrow \Phi) \rightarrow \Phi)$

この $\Phi \rightarrow((\Phi \rightarrow \Phi) \rightarrow \Phi)$ の場合, それぞれの判断の左辺に登場している 証明項（ラムダ項）は，タイプ付けが行われているため一見見て取りづらい が, 要するに, 型自由ラムダ計算でよく知られている「チャーチ数項 (Church numeral)」に一致している. 実際, 例えば一番目と二番目は, 型を除去して 書けば

$$
0=\lambda \mathrm{x} \lambda \mathrm{y} \cdot \mathrm{x} \quad 1=\lambda \mathrm{x} \lambda \mathrm{y} \cdot \mathrm{y}(\mathrm{x})
$$

である。一般にチャーチ数項が, 任意の演算, 操作といったものの反復的適 用の回数をコード化している（0であれば，0回の適用，1であれば 1 回の適 用，等々）という点で，(型自由ラムダ計算の体系における計算上の振る舞い の観点から見て）自然数に相当することは言うまでもない.これに対応して， 例えば，上の $\lambda \mathrm{x}: \Phi \lambda \mathrm{y}: \Phi \rightarrow \Phi . \mathrm{x}$ は，構造 $\Phi$ という一つの世界にとっての 0 


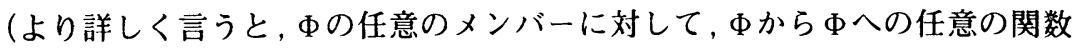
を 0 回適用することをコード化した関数）だと考えることができる．かくし て, 命題 $\Phi \rightarrow((\Phi \rightarrow \Phi) \rightarrow \Phi)$ に対応させられる各証明項は, いわば「構造 $\Phi に$ 対して相対化された（構造 $\Phi$ 上の）自然数」であり，従ってまた，この 命題自身は，それらの「構造 $\Phi$ に相対化された自然数」たち全体をメンバー とする (「居住者 (inhabitant)」とする)一つの構造, つまり，「構造 $\Phi に$ 相 対化された自然数領域」を成していることになる.

そこで更に，以上に対する命題全称量化を行ったとしよう。その結果は，次 の通りである。

[Fによる自然数タイプの構成 $]$

$\Lambda \Phi \lambda \mathrm{x}: \Phi \lambda \mathrm{y}: \Phi \rightarrow \Phi . \mathrm{x}: \Pi \Phi . \Phi \rightarrow((\Phi \rightarrow \Phi) \rightarrow \Phi)$

$\Lambda \Phi \lambda \mathrm{x}: \Phi \lambda \mathrm{y}: \Phi \rightarrow \Phi . \mathbf{y}(\mathbf{x}): \Pi \Phi . \Phi \rightarrow((\Phi \rightarrow \Phi) \rightarrow \Phi)$

$\Lambda \Phi \lambda \mathbf{x}: \Phi \lambda \mathbf{y}: \Phi \rightarrow \Phi . \mathbf{y}(\mathbf{y}(\mathbf{x})): \Pi \Phi . \Phi \rightarrow((\Phi \rightarrow \Phi) \rightarrow \Phi)$

$\Lambda \Phi \lambda \mathrm{x}: \Phi \lambda \mathrm{y}: \Phi \rightarrow \Phi . \mathrm{y}(\ldots(\mathrm{y}(\mathrm{y}(\mathrm{x}))) \ldots):$ II $\Phi . \Phi \rightarrow((\Phi \rightarrow \Phi) \rightarrow \Phi)$

ここでは命題変項（タイプ変項） $\Phi$ が全称量化されることにより, 先のよ うな個々の構造への相対化が排除され，端的な自然数領域(自然数タイプ) と しての川 $\Phi . \Phi \rightarrow((\Phi \rightarrow \Phi) \rightarrow \Phi)$ が得られていることが理解されるだろう. 言い換えれば，この領域の居住者である各証明項（ラムダ項）は，それぞれ 一個の端的な自然数と考えてよいものである. (各左辺の先頭にある「 $\Lambda \Phi 」$ は, 命題変項に対するラムダ抽象の表現であり, すなわち, 各左辺のラムダ 項は, 種々の命題記号，つまりタイプ項に適用されて，そのタイプ上の自然 数へと簡約されることになる。この意味で，これらは各タイプ，各構造に相 対化された自然数の一般的な代表である).

というわけで, 少々話が先走りすぎたが，(高階)命題論理とそれに重ね合 わせられたラムダ計算の言語という，体系 $\mathrm{F}$ の言語的枠組み——それは，命 題論理については条件法結合子, 全称量化子, またラムダ計算については, 通 常通り，ただのラムダ演算子を含むのみだという意味で，やはりここで言う “純粋な言語”である——立つと，冒頭に見たNCとは大きく異なった仕方 ではあるが，いま見たような自然数領域を始めとする，広範な数学的構造の 構成を行うことが可能となる（しかももちろん，こちらの場合は始めからパ ラドクスを免れている）ことが，大よそ理解されるであろう。

そこで改めて，以上のような対照が何に基づき，また何を意味するのかを， 特に, 或る種の意味理論的な観点から若干検討してみることにしたい. 
まず, 冒頭で述べたNCをもう少し詳しく特定し，包括原理の中身を確認し ておくことにする.標準的な古典一階述語論理の言語しを用意し（推論規則も 通常の古典論理通りとする——だし, 矛盾の導出のためだけであれば, 直観 主義論理でも十分であるが，ここでは措く），そこに次のような拡張を加える。 （1）クラス演算子（class operator）：対象変項（「x」で代表させる）の自 由な出現を含む任意の開放式 $\Phi[\mathbf{x}]$ に適用可能で, その結果, 形成されるク ラス抽象，すなわち

$$
\{\mathrm{x} \mid \Phi[\mathrm{x}]\}
$$

は，対象タームである。ここで $\Phi$ 中の $\mathrm{x}$ の自由な出現は，すべて束縛されて

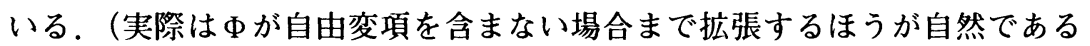
が, ここでは立ち入らない)。

(2) メンバー関係記号「ヒ」：次の [述定原理] を満たす（他に，ふつうは 外延性公理も置かれるわけだが, やはりここではさしあたり必要でないので 取り上げない)。

[述定原理 $\quad \forall \mathrm{y}(\mathrm{y} \in\{\mathrm{x} \mid \Phi[\mathrm{x}]\} \leftrightarrow \Phi[\mathrm{x}:=\mathrm{y}])$

(ここで $\Phi[\mathrm{x}:=\mathrm{y}]$ は， $\Phi[\mathrm{x}]$ 中の $\mathrm{x}$ の自由な出現をすべて $\mathrm{y}$ に置き換えた 結果である).

この設定の下で，[述定原理］中の $\Phi[\mathrm{x}]$ として 全称量化子 $\mathrm{y}$ を, クラス抽象 $\{\mathrm{x} \mid \neg \mathrm{x} \in \mathrm{x}\}$ で例化すれば, ラッセルのパ ラドクスに当たる同值関係,

[RP] $\{\mathrm{x} \mid \neg \mathrm{x} \in \mathrm{x}\} \in\{\mathrm{x} \mid \neg \mathrm{x} \in \mathrm{x}\} \leftrightarrow \neg\{\mathrm{x} \mid \neg \mathrm{x} \in \mathrm{x}\} \in\{\mathrm{x} \mid \neg \mathrm{x} \in \mathrm{x}\}$

が導かれ、ここから標準的推論によって矛盾が導かれることは周知の通り である。

以上がNCで定式化した包括原理, 及びラッセルのパラドクスであるが，こ こでまず注目してよいと思われるのは，近年広く指摘されるようになってき た次の事実，つまり，クラス演算子とは，実は，他ならぬラムダ演算子（関 数抽象演算子 (abstraction operator)) の一種, その特別な形である, とい う点である.ラムダ演算子とは，まず一言で言えば，一般に何らかの表現(ラ ムダ項）に適用されてその中の或る変項のすべての自由な出現を束縛するこ 
とにより，一つの抽象表現（ラムダ抽象）を形成する演算子のことであり，そ の際，この抽象表現が抽出しているのは，基本的に或る種の関数だと考えて よい。(それが関数だと言える理由は，すぐ後で確認する）。恋項束縛 （variable-binding）という一見トリヴィアルに見えかねない構文論的機能 が, 実際にはどれほど強力で複雑な抽象表現の形成能力を持つかは，ラムダ 計算の諸体系を通じてよく知られているところだろう.クラス演算子が持つ, 多様なクラス抽象を形成しうる力能も，根本的には，それが本来のラムダ演 算子として備えているこの変項束縛の働きに基づいている. 以下，もう少し 詳しく，ラムダ演算子の三つの本質的特性を確認し，その上でクラス演算子 がどのような点で特殊化されているかを見てみよう。

(1) 変項束縛 (variable-binding) を行うこと. 何であれ, 或る表現（ラムダ

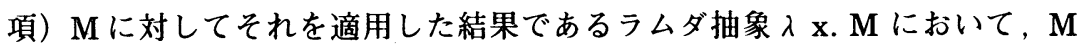
中の $\mathrm{x}$ の自由な出現はすべて束縛されている。

(2) 適用 (application) が可能であること. $\lambda \mathrm{x} . \mathrm{M}$ の場合, 任意の表現（ラ ムダ項） $\mathrm{N}$ に対して適用されて，いわゆる簡約可能項（ $\beta$-redex）である

$$
(\lambda \mathbf{x} . \mathrm{M}) \mathrm{N}
$$

を形成する.

(3) 簡約 (contraction) が可能であること.ラムダ計算においては, 簡約可 能項 ( $\lambda \mathrm{x} . \mathrm{M}) \mathrm{N}$ と, その既約項 (contractum) である $\mathrm{M}[\mathrm{x}:=\mathrm{y}]$ の間に は, 簡約関係, すなわち
[簡約関係]
$(\lambda \mathrm{x} . \mathrm{M}) \mathrm{N}$
$\Rightarrow$
$\mathrm{M}[\mathrm{x}:=\mathrm{N}]$

が成り立つ. 簡約関係は, 基本的には両項の間の同一性関係と考えてよいも のであるが, 実際はもっときめの細かい概念で, 一般に簡約可能項とその既 約項との間には, 前者から後者に向かう計算プロセス（値評価）の進展が含 まれると見なしうる。しかしその点は，ここでは措くとして，いずれにせよ， こうした簡約関係のおかげで, ラムダ抽象 $\lambda \mathrm{x} . \mathrm{M}$ を或る種の関数の表現であ る（関数を抽出している）と見なすことが可能となる．なぜなら，任意の表



$$
\mathrm{N} \mapsto \mathrm{M}[\mathrm{x}:=\mathrm{N}]
$$

という関数的な対応関係があるが，入x. Mは，それが各 $\mathrm{N}$ に適用されると $\mathrm{M}[$ $\mathrm{x}:=\mathrm{N}]$ ○と簡約されうる（值評価の結果として $\mathrm{M}[\mathrm{x}:=\mathrm{N}]$ ]与える）もので ある以上,この関係を明示的な抽象表現としてコード化したものに他ならない と言えるからである。(簡約の操作は，このコードの解読として機能してい る).ただし同時に, 簡約関係は, あくまで具体的に与えられる（ラムダ項と して言語内に存在する） $\mathrm{N}$ との関わりにおいてのみ, $\lambda \mathrm{x} . \mathrm{M}$ の振る舞い, 意 
味を定めるだけである（つまり，いわゆる操作意味論を与えるだけである）か ら，こうした範囲を超えて，入 x. M がそれ自体で何を表示するかを定めよう とすると，その決定はモデル論的な解釈 (表示意味論) に属することになる.

他方, クラス演算子はどうだろうか.(1)の変項束縛については, 既に見た 通りであるし，(2)の適用について言えば，クラス抽象の場合も，メンバー記 号を用いることで，任意の対象ターム $\mathrm{t}$ に適用されて，式 $\mathrm{t} \in\{\mathrm{x} \mid \Phi[\mathrm{x}]\}$ を形成するそそして(3)の［簡約関係］については，[述定原理］がそれに対 応することも明らかだろう. 要するに, クラス演算子とは, 一言で言って, 通 常の述語論理（NCの場合で言えばL）のタイプ構造の中に一定の仕方で組み 込まれた限りでの，ラムダ演算子に他ならないということである.

ところでそれでは，この最後の事実一クラス演算子が述語論理のタイプ構 造に埋め込まれていること一は, クラス演算子にどのような影響を与えてい るだろうか。第一に，ラムダ抽象の場合は，「型自由（type-free）」なラムダ 計算の体系では, タイプは一切付与されないし，「型付」の体系では，きわめ て豊富なタイプ構造の下でのタイプ付けが行われるが,これに対して, クラ 不抽象の場合は，もっぱら固定的に対象タームとしてタイプ付けられること になる。ここから生じる一つの結果は, 型自由と型付の両面を含んだ錯綜し た性格である．なぜなら，一方でクラス抽象はすべて自己適用可能となるし (この点では型自由と同じである)，他方で，クラス抽象が任意の対象ターム に適用された結果は，式（命題）となり，もはや対象タームに対して適用で きなくなるからである(この点では型自由と異なる)。しかしこうした問題は ひとまず措くとして（少し後で，公理的集合論との関係でこの問題に触れ る)，いずれにせよはっきりしているのは, クラス抽象が表示するものは，そ れ自体としては対象だと見なさねばならないということである.

第二に，しかもそれにもかかわらず，クラス抽象が抽出したものは，やは り或る種の関数だと見なすべき理由がある，なぜなら，まず一方で，それは ラムダ抽象の場合の簡約関係に相当する [述定原理］を満たしており, 従っ て，少なくともラムダ抽象が（上で見た通り）関数と見なされるべきである のと同等の範囲で，やはり関数だからである．また他方で，それ以上に，ク ラス抽象〔 $\mathrm{x} \mid \Phi[\mathrm{x}]$ ] の元となっている開放式 $\Phi[\mathrm{x}]$ は, 対象領域中の端 的に「すべての対象」について有意味である（各対象によって二值的に充足 さるかされないかである）ところの，きわめて実在論的な性質，命題関数，概 念といったもの (真理值を值とする関数)のはずだからである.もちろん, こ の二值性を要求してしまう限り, 決してパラドクスから逃れえなくなるから， このポイントを過度に強調すると, 結局クラス抽象とは矛盾した概念だ，と 
いうことで話が終わってしまう．だがともかくも，以上を踏まえれば，クラ 不抽象が表示するのは, 〈対象化, 物化された或る種の関数〉として特徴付け るのが最も理に適っていることが理解されるだろう.

ここで本稿の本来の関心事に戻ろう。クラス演算子が持つ一つの興味は, それが (開放式への適用という操作を介して) きわめて多様な構造 (集合, ク ラス）の構成を行いうる（そのままでは矛盾を含んではいても，そうした構 成の一つのやり方を示している）点にあった。しかしそれでは, 結局のとこ ろクラス演算子は，一般に構造をいかなる存在物として構成していることに なるだろうか. 以上までに見たことを踏まえれば，答えは明らかと言ってよ いだろう。すなわち，クラス演算子の適用を介して，クラス抽象という言語 的形式の下に構成されるところの当の構造そのものとは, 端的に（対象化さ れた）或る種の関数に他ならない，ということである.

それだけでなく，更に次のことも言える．まず第一に，構造のメンバーと なっているものも，一般にはそれ自体，(対象化された）関数だということで ある. 冒頭で見た， NCによる自然数 0 と自然数領域 $\mathrm{N}$ との定義を想起しよ う. Nはもちろんクラス，すなわち（対象化された）関数であるが，そのメ ンバーである 0 もクラス抽象によって抽出された（対象化された）関数であ るのに他ならない（すべての対象構成を,クラス抽象によって賄抢うとする のである以上, 当然に過ぎないことではあるが). 更に第二に, 構造とそのメ ンバーとの間の関係，つまり「€」関係は，一般的な言い方をすれば充足の 関係であるが，より具体的には，少なくともメンバーがそれ自身，対象ター ムの形を採って(つまり，一定の対象タームによって表示されたものとして) 言語の中に明示的に登場しうるものである限り，ラムダ計算的な意味での簡 約関係そのものである.(それが, クラス演算子は本来ラムダ演算子であると いう事実の教えるところである).

というわけで, 以上を一旦整理してみると, 次の通りとなる.

「構 造」

[包括原理］（対象化された）関数
「メンバー」

（対象化された）関数
「両者の関係」 簡約, 充足

この点で, 前節で見た高階タイプ理論的な構造構成の手法との対比を行っ てみることは，かなり興味深い。タイプ理論に従えば, 構造（タイプ）とは 命題そのもの，あるいは少なくとも，命題記号によって表示される当のもの であり, 実際, 自然数領域もその一つだった。この場合, 命題とは何かとい うことを直接的に形而上学的に突き詰めようとしてもあまり得るところはな 
いだろう。しかしながらはっきりしているのは，このとき同時に，タイプ理 論的な見方に従えば，一般に関数であるものは，構造そのものではなく，あ くまで構造のメンバーでなければならない，ということである。実際, 自然 数タイプの場合で言えば，そのメンバーである 0,1 等の各々の自然数は，一 定のラムダ項によってコード化された関数であるのに他ならない. 更に，こ うしたメンバーとしての関数と, それを包椇する構造そのものとの間の関係 も, 包括原理の場合とははっきり異なる. 詳しくは次節に譲るが, それは充 足, 簡約の関係ではなく,(1)論理学的に言えば, 証明と, それによって証明 される命題との関係であり，あるいはまた,(2)数学的に言えば，関数と，そ の関数の文字通りの「タイプ」(つまり，関数の定義域及び值域による分類） であり，すなわち，いわゆる居住関係に他ならない，従って，上と類比的に 整理してみると, 次のようになる。

\section{「構造」「メンバー」「両者の関係」 \\ [タイプ理論］命題, タイプ 関 数証明, 居住}

というわけで，以下ではタイプ理論の枠組みをもっと丁寧に見ることに するが,ただしそれは次節に譲り，その前に以下の諸点を指摘しておきたい．

以上のように見てくると，包括原理の観点と，タイプ理論の観点は，一方 的に対立点のみが目に留まる。しかしながら，ここでZF集合論のような公理 的集合論について併せて参照してみると，問題はそう単純ではないことが 判ってくる．なぜなら，公理的集合論が包括原理の一定の継承者であること は明らかであるにもかかわらず，その公理的集合論が包括原理のうちで切り 捨てた一つの要素を，或る種の仕方でタイプ理論はむしろ受け継ぎ，あるい は異なった観点から再生させていると考えられるからである.その要素とは， 一言で言えば，一定の明確に構造化された言語表現形式に従った，数学的構 造の構成の遂行ということに他ならない，具体的に言えば，そうした表現形 式とは，包括原理の場合は，もちろんクラス抽象であり，タイプ理論で言え ば，判断形式，とりわけその右辺に登場する，命題論理の結合子及び量化子 一いわゆるタイプ構成子 (type constructor)——適用に基づく構造構成 である. 公理的集合論が, ラッセルのパラドクス回避のために端的に捨て 去ったものの一つが, まさにこうした言語表現様式であったことは改めて述 べるまでもないであろう。(実際, 公理的集合論にとって, パラドクスに対す る端的な対処策とは，クラス演算子を放棄することだった）.

更にもう一言，公理的集合論について補足したいことがある。それはすな 
わち, 以上と逆に,この集合論が守ろうとしたものは何であったのかという 問題である。筆者の誤認でなければ，この点は極めてはっきりしていると思 われる.すなわち，すぐ上で掲げた，包括原理の形而上学的枠組み，つまり， 構造もメンバーも一様に（対象化された）関数として構成し，両者の間の関 係を充足，簡約として与える，という形而上学的枠組みに他ならない。一見 すると，公理的集合論については，そこで主題となっている当の概念，すな わち集合概念は，文字通りに実在論的で，かつ対象的・物的であり，このよ うな概念を何らかの関数として説明すること（同様にまた，そこでのメン バー関係を充足，簡約として説明してしまうこと）は，あまりにも無理があ るように思われるかもしれない。確かにそうなのかもしれないが，しかし或 る程度立ち入って考えてみると，集合論にとって集合が或る種の「型自由な 関数」に近いものであることが不可欠なのは，ほとんど疑いえないように思 われる.

実際，集合論の基軸にあるのは，よく知られている通り，いわゆる「構造 を飛び出す（jump out）こと」が可能であること，つまり，いかなる集合に ついても，必ずそのメンバーではないような集合を構成することができるこ と, という大変ダイナミックなアイデアである，あるいは言い換えれば，決 して全包括的な集合は存在せず，いかなる集合を採ろうとも，必ずそれより 更に包括的な集合が存在する，ということに他ならない。しかしながら，こ のことの論証が可能となるのは,一般的に言って対角線論法によってであり， そしてこの論法は基本的に常に自己適用,そしてその簡約ということを含む. 例えば，最も単純だが重要な次のような集合論の定理，すなわち，


の論証を想起してみよう。周知の通り，これはほとんど文字通り，ラッセル のパラドクスそのものの応用であり, 分出公理によるその帰謬法的解決であ る.すなわち，いま，

$$
\mathrm{X}=\{\mathrm{x} \mid \mathrm{x} \in \mathrm{A} \wedge \neg \mathrm{x} \in \mathrm{x}\}
$$

を採る．(これは分出公理によって正当化される)。これ自身既に自己適用を 含むが, 更にこれを自己適用してやれば，まったくの簡約そのものに従って，

$$
\mathrm{X} \in \mathrm{X} \leftrightarrow \mathrm{X} \in \mathrm{A} \wedge \neg \mathrm{X} \in \mathrm{X}
$$

が䚻結する。そしてここからは，簡単な帰謬法によってつ $\mathrm{X} \in \mathrm{A}$ が州結する のに他ならない.

このように，自己適用と簡約を中核とする集合概念は，第一義的には，或 る種の型自由な関数として捉えるのが最も適切なのではないだろうか. 残念 ながらこれ以上立ち入る余裕も準備もないが, まったくの断定として述べて 
しまうと, パラドクスからの脱却策として公理的集合論が行ったことは，ク ラス演算子によって抽出しうる範囲の関数を遥かに凌駕するく対象化された 型自由的な関数〉の実在を，一連の存在公理の要請によって一挙に獲得する ということに他ならなかったように思われる。

というところで, タイプ理論の検討に戻ることにしよう.

3

ここでは，残念ながら高階タイプ理論まで踏み込む余裕はないが，最も初 等的な単純タイプ理論については，ほぼ概要を見ることができる．既に述べ た通り，一般にタイプ理論の言語は，「判断 (judgment)」と呼ばれる次の形 の記号結合を基本単位としている。

[判断図式] $\mathrm{N}: \Phi$


なるが, しかし実際には, この同じ判断が, 少なくとも以下のような二つの 読みを許すことが判明する。

（1）論理学的（意味論的）読み 証明 N（ラムダ項 Nによってコード化

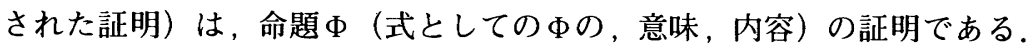

(2) 数学的読み 関数 N（ラムダ項 Nによってコード化されている数学


ある。

第一節で紹介した判断の例, すなわち,

$$
\lambda \mathrm{x}: \Phi \lambda \mathrm{y}: \Phi \rightarrow \Phi . \mathrm{x}: \Phi \rightarrow((\Phi \rightarrow \Phi) \rightarrow \Phi)
$$

で言えば, 論理学的読みとしては, 通常の命題論理に従って, 「左辺のラムダ 項によってコード化された証明は, 命題 $\Phi \rightarrow((\Phi \rightarrow \Phi) \rightarrow \Phi)$ の証明である」 となり，数学的読みとしては,「左辺のラムダ項によってコード化された関数 は, 構造 (タイプ) $\Phi \rightarrow((\Phi \rightarrow \Phi) \rightarrow \Phi)$ の居住者である」となる.こうし た二重の読みの一致が生じるのは，一言で言えば，すぐ後に掲げる P $\Lambda$ の推 論（型付け）規則 [P $\Lambda$ 1] - [P $\Lambda$ 3] が, どちらの読みの下でもまったく


$\mathrm{W} \cdot \mathrm{A} ・$ ・ワードにちなんで「カリー=ハワード対応 (Curry-Howard Isomorphism)」と呼ばれる)。そのことがいかなる概念的興味を持つかは後 に譲り，まずその実際を見よう。ここでは，論理学的読みの方を先立たせて， $\mathrm{P} \Lambda$ を通常の（命題）論理のわずかな拡張として概説し，その上で，そこで 
起こっていることが, 数学的構造の構成とも解しうるものでもあることを説 明する。

結合子として条件法記号「 $\rightarrow 」$ のを持つ, 自然演繹型の命題論理の言語 $\mathrm{P}$ を考える. $\mathrm{P}$ は命題変項 (無限個) として $\alpha, \beta, \gamma$ 等を含む（原始命題定 項はあってもよいが, 特に必要ない). 以下, $\mathrm{P}$ の式 (命題記号) を代理する メタ記号として $\Phi ， \Psi$ 等を, また, 式列を代理するメタ記号として $\Gamma$ 等を用 いる。推論規則は, 次の通りである（シークエント・スタイルで書く）。

[P1] $\Gamma, \Phi \vdash \Phi$

[P2]

$$
\frac{\Gamma \vdash \Phi \quad \Gamma \vdash \Phi \rightarrow \Psi}{\Gamma \vdash \Psi}
$$

[P3]

$$
\frac{\Gamma, \Phi \vdash \Psi}{\Gamma \vdash \Phi \rightarrow \Psi}
$$

そこで次に，Pを $\mathrm{P} \Lambda$ へと拡張しよう。用語上， $\mathrm{P}$ の命題変項を「タイプ 変項」, 式を「タイプ項」とも呼ぶ。新たに，v1，v2，...といった（無限個 の）変項を導入し，これらを「ラムダ変項」と呼ぶ. 以下，ラムダ変項を代 理するメ夕記号として, $\mathrm{x}, \mathrm{y}, \mathrm{z}$ 等を用いる. 更に, ラムダ変項の束縛のため の演算子 $\lambda$ を導入する. ラムダ変項とラムダ演算子を用いて，次の規則に 従って形成される諸表現を「ラムダ項」と呼ぶ（以下，ラムダ項を代理する メタ記号として $\mathrm{M}, \mathrm{N}$ 等を用いる)。

[(型付) ラムダ項形成規則]

(1) 任意のラムダ変項 $\mathrm{x}$ は，ラムダ項である.

（2）任意のラムダ項 $\mathrm{M}, \mathrm{N}$ について， Nへの M の適用形 $\mathrm{MN}$ は，ラムダ項 である.

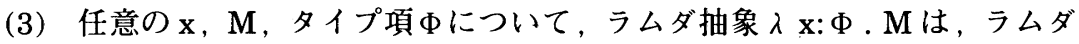
項である.

ラムダ変項 $\mathrm{x}$ タイプ項 $\Phi$ と,次のように判断の形に結合したものを「原 子判断」と呼ぼう.
[原子判断]
$\mathrm{x}: \Phi$

このとき「 $\mathrm{x}$ は $\Phi に$ 型付けられている」と言う. 原子判断の式列 $\Gamma$ が与え られているとき，そこに登場しているラムダ変項のいずれかが，複数の異 なったタイプ項に型付けられている場合，「は「不整合」であると言う。そ うしたことがない場合（どのラムダ変項も，ただ一つのタイプ項だけに型付 けられている場合)「整合的」であると言う。そこで，ラムダ項とタイプ項を 対応付けるための推論規則として, 先の [P1] - [P3] を次のように拡張し たものを置く．ただしこのとき，「は原子判断のみから成る式列とする．ま 
た，どのシークエントにおいても，その先行列（左辺）は整合的であるもの とする.

$\begin{array}{ll}{\left[\begin{array}{lll}\mathrm{P} & \wedge & 1\end{array}\right]} & \Gamma, \mathbf{x}: \Phi \vdash \mathbf{x}: \Phi \\ {\left[\begin{array}{lll}P & \wedge & 2\end{array}\right]} & \frac{\Gamma \vdash \mathrm{M}: \Phi \quad \Gamma \vdash \mathrm{N}: \Phi \rightarrow \Psi}{\Gamma \vdash \mathrm{NM}: \Psi}\end{array}$

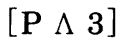

$$
\frac{\Gamma, \mathbf{x}: \Phi \vdash \mathrm{M}: \Psi}{\Gamma \vdash \lambda \mathrm{x}: \Phi \cdot \mathrm{M}: \Phi \rightarrow \Psi}
$$

さて, 論理学的な読みから考えよう。この場合，これらの規則について必 要なのは, 単に, それぞれの段階での証明を当該のラムダ項によってコード 化するのが適切であるということの正当化のみである. 例えば, $[\mathrm{P} \Lambda 3]$ に

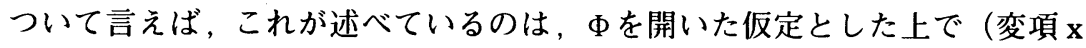



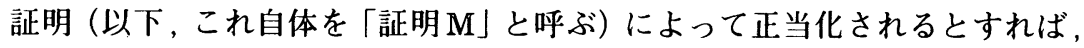
そのとき， $\Phi \rightarrow \Psi$ が，コード $\lambda \mathrm{x}: \Phi . \mathrm{M}$ に対応する証明（以下，「証明 $\lambda \mathrm{x}$

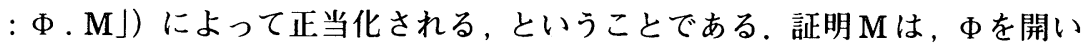
た仮定として含みうる $\Psi$ 証明である。つまりそれは，開いた仮定 $\Phi に$ 代え

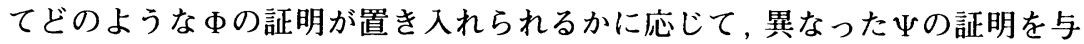
える. 従って, これらの開いた仮定 $の$ 出現ステップを閉じれば，そうした 依存が破棄され， $\Phi \rightarrow \Psi の$ 証明が得られる。これがすなわち証明入 $\mathrm{x}: \Phi . \mathrm{M}$ に他ならない，すると，この証明が，こうしたラムダ抽象によってコード化 されているのは当然である. ラムダ項としての $\lambda \mathrm{x}: \Phi . \mathrm{M}$ は, 証明 $\mathrm{M}$ のコー ド（ラムダ項としての M) 中の，開いた仮定 のコード $\mathrm{x}$ の出現を束縛して いるからである.

次に数学的読みを考えてみよう。ここではむしろ，各ラムダ項が数学的関 数をコード化するやり方は前提となる. 規則によって行われているのは，タ

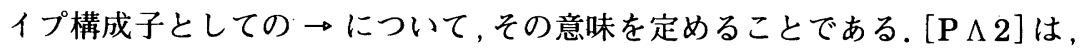
関数 $\mathrm{M}$ が構造 $\Phi$ の居住者であること, 及び, 関数 $\mathrm{N}$ が構造 $\Phi \rightarrow \Psi$ 居住者で あることが確立済みであるとき，関数 NM (関数 $\mathrm{N}$ を関数 $\mathrm{M}$ に適用した結果) が構造 $\Psi$ 居住者であることが確立される，ということである。言い換えれ ば, 構造 $\Phi \rightarrow \Psi$ とは, その居住者 $\mathrm{N}$ が構造 $\Phi$ の居住者 $\mathrm{M}$ に適用されるとき,

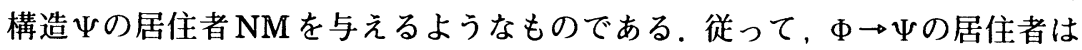

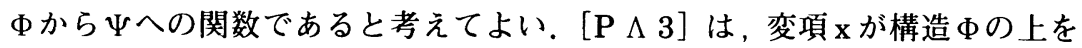

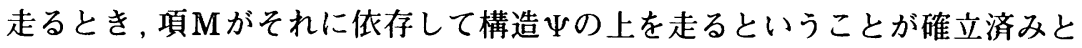

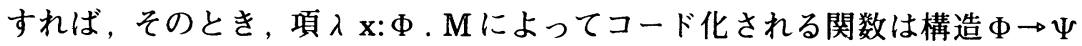
の居住者であることが確立される, ということである. 項 $\lambda \mathbf{x}: \Phi . \mathrm{M}$ は, 変 
項 $\mathrm{x}$ に対する項 $\mathrm{M}$ の依存を廃棄（束縛）した結果であるから，この項が表示す る関数は， $\Phi$ から $\Psi$ の関数である. 構造 $\Phi \rightarrow \Psi$ は, このような項 $\lambda \mathrm{x}: \Phi . \mathrm{M}$ が表示する関数がその居住者となる構造として, $\Phi$ か $\Psi$ への関数空間であ る.

さて，以上の二つの正当化がともに成功だとすると，次が言える．すなわ ち, 二つの読みの中身をどれくらい文字通りに同一視するか（証明すなわち 数学的関数, 命題すなわち数学的構造, と見なすか) は, 必ずしも簡単では

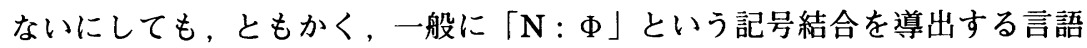
的操作が, 命題としての $\Phi$ の証明 $\mathrm{N}$ の構成であるとともに，そのことによっ て, 構造としての $\Phi$ (命題としての $\Phi$ とは異なっていてもよいとして）のメ ンバーN（これも，証明としての $\mathrm{N}$ とは異なっていてもよいとして）の構成

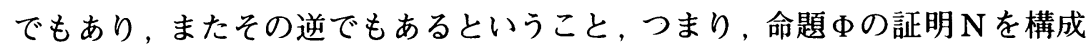
することと, 構造 $\Phi$ のメンバー $\mathrm{N}$ を構成することとは, 必ず互いを含む, 伴 う，ということである。このゆえに我々は，例えば，一つの数学的構造 $\Phi \rightarrow$ $\Phi$ と, その居住者 $\lambda \mathrm{x}: \Phi . \mathrm{x}$ ( $\Phi$ 上の恒等関数) を構成するために，この構造 及び居住者にアクセスするための特別な心的・因果的結び付きといったもの を無理に求める必要なく, 単に, 初等的命題論理で行われる通りのその証明 を行いさえすればよい（それによって既に当の構造は“アクセス”されてい る）ということになる。

こうしたカリー=ハワード対応的な考えは, 未だ吟味を要求される部分が 多々残るが（例えば，数学的なデータ・タイプは命題の宇宙を容易に包含す るほどの包括性を持つと考えるのが自然であるし，自然数領域を第一節で見 たような $\Pi \Phi . \Phi \rightarrow((\Phi \rightarrow \Phi) \rightarrow \Phi)$ として構成するのが数学的に十分適切 かどうかも議論が分かれる)，いずれにせよ，包括原理においては開放式に対 するクラス演算子の適用という仕方で，また公理的集合論（分出公理）にお いては開放式を介する分出という仕方で，いずれも基本的には或る種の関数 抽出として行われる数学的構造の構成が，ここではそうではなく，命題の構 成そのもの（及び，それと一致して進む証明の構成）を介して遂行されると いう点は, 十分に興味深いと評すべきだろう。

とはいえ，むしろ筆者が以上を通じて最も指摘したいのは次の点である. いまも述べた通り，包括原理においても分出公理においても，もっぱら関数 抽出という手段が構造構成の基礎に置かれてきたのはなぜだろうか. なぜ， カリー=ハワード対応における命題の構成操作のような, もっと基礎的で一 般的な言語操作が, 構造構成の力能を持つ手段として認められてこなかった のだろうか。ここに控えているのは, 明らかに言語の意味理論上の見解に関 
わる問題だと思われる，すなわち，包括原理の主要な支持者であったフレー ゲを始め, ラッセルのパラドクス当時の代表的な論理学者, 数学者たちはい ずれも，開放文には抽象されるべき関数がその意味として伴っていると信じ， 他方, 命題のようなものに構成操作の対象となりうるような意味が担われて いるとは思いもよらなかった, ということである。このことだけから, 論理 学, 及びそれに関する哲学的考察にとって, 何か価值のある教訓や洞察が直 ちに得られるかどうかはもちろん明らかではない。しかしいずれにせよ, 次 のような事実は，おそらく多くの人に，少々意外ではありながら，十分興味 深いこととして受け止められるのではないだろうか. すなわち, 数学的構造 の構成がいかにして行われるべきかという問題は, 言語の意昧の問題と深く 結び付いてきたし，いまもそうであり続けている，ということである.

\section{註}

1.これはグリシン集合論である。これについて筆者は，第 35 回科学哲学会大会の ワーク・ショップ「ラッセルのパラドックス・100年」の席上で, 照井一成氏の 発表を通じて初めて詳しく知った. 本号に掲載予定の同氏の論文を参照されたい. 2.これはJ.-Y. ジラールの開発した体系である. 文献[1], 特にその11章以下を参照.

\section{参考文献}

[1] J.-Y. Girard, Y. Lafont and P. Taylor, "Proofs and Types", Cambridge Tracts in Theoretical Computer Science 7, Cambridge University Press, Cambridge, 1989.

[2] J. R. Hindley and J. P. Seldin, "Introduction to Combinators and $\lambda$-calculus", London Mathematical Society Student Texts 1, Cambridge University Press, Cambridge, 1986.

[3] W. A. Howard, 'The formulae-as-types notion of construction', in J. R. Hindley and J. P. Seldin (eds.), "To H. B. Curry: Essays on Combinatory Logic, Lambda Calculus and Formalism", Academic Press, 1980, pp. 257-267.

(東京都立大学) 